ISSN 0206-5657. Вісник Львівського університету. Серія біологічна. 2021 Випуск 84. С. 84-93 Visnyk of the Lviv University. Series Biology. 2021. Issue 84. P. 84-93

УДК 504.064.36:574

https://doi.org/10.30970/vlubs.2021.84.08

\title{
ASSESSMENT OF ECOTOXICAL STATE OF TECHNOLOGICALLY MODIFIED EDAPHOTOPES WITH WASTE OF OIL REFINERY WITH THE ALLIUM-TEST METHOD
}

\author{
H. Klepach ${ }^{\text {* }}$, N. Holub², O. Lupak ${ }^{1}$ \\ ${ }^{1}$ Drohobych Ivan Franko State Pedagogical University \\ 24, I. Franko St., Drohobych 82100, Ukraine \\ e-mail:pavlishko@yahoo.com \\ ${ }^{2}$ Ivan Franko National University of Lviv \\ 4, Hrushevskyi St., Lviv 79005, Ukraine \\ e-mail: nataliia.holub@lnu.edu.ua
}

\begin{abstract}
The ecotoxic state of technologically modified edaphotopes by waste of refinery was investigated with the Allium-test method. Material for the investigations was samples of edaphotopes which were selected at a depth of 15-20 cm from seven research areas of different locations. The last ones were 10-200 m away in relation to the surface storages of oil sludge and other waste of refinery. It has been detected in Allium-test that edaphotopes of the research areas located at a distance of 10-50 m relative to the storages of waste are toxic. Particularly, their aqueous extracts cause a medium and high level of phyto-, cyto- and genotoxic effects on the growing and proliferative activity of Allium cepa Stuttgarter Riesen variety meristem. Test extracts of edaphotopes in growing Allium-test caused darkening of rootlets and blackening of their tips (contrary to the light rootlets with light tips in control). In addition to it the growing activity of $A$. cepa bulb roots that were grown on the aqueous extracts of edaphotopes was decreased in 1.71-3.5 times depending on the location and measure of remoteness of the research area from the storage of waste of the refinery. Phytotoxicity of aqueous extracts of those edaphotopes regarding to $A$. cepa is above average and higher levels, and tolerance of onion rootlets to the test extracts decreases up to 29-52\% comparing to control. The mitotic activity of apical meristem of rootlets also decreased. Particularly, mitotic indexes diminished to $51.05-63.57 \%$ (in control $-82.34 \%$ ) and cytotoxicity ones were in the range of $22.8-48.0 \%$ that confirms the medial level of cytotoxicity of the investigated edaphotopes. Ana-telophase method and micronucleus test have shown that the chromosome aberrations frequency and appearance of micronuclei in the cells of the apical meristem of the test object $A$. cepa is higher in 3.34-5.20 times comparing to control. It indicates the average and the high level of genotoxicity of the investigated edaphotopes. The edaphotopes, which are located at the distance of 100-200 $\mathrm{m}$ in relation to the surface storages of waste of refinery have a slight phyto-, cyto- and genotoxic effects which are close to the background level.
\end{abstract}

Keywords: waste of oil refinery, edaphotopes, Allium-test, ecotoxicity

Oil refineries (ORs) are strong pollutants of the environment during the last century. Despite of introduction of up-to-date technologies of oil processing, some of ORs continue generating a big volumes of exhausted fumes into the environment. A great danger for the environment has their surface storages where oil-slimes and other waste of oil processing are dumped. Concentrating in soils adjacent to oil-slime storages and spreading along ground horizons they cause the negative changes of all their characteristics. Significant or partial soil pollution with oil-slimes leads to the change of physical, physico-chemical and chemical characteristics of soil. The level of these changes depends on the type of soil and its initial state as well as the kind and number of pollutants [3].

(c) Клепач Г., Голуб Н., Лупак О., 2021 
Among oil-slimes there is a number of substances which penetrate into soil and cause genotoxic action: they can enhance the intensity of natural mutation in ten and hundred times. Some of them are carcinogens, some - co-mutagenes. Nowadays mutagenic effects of chemical compounds (chemical mutagenesis) is in the centre of genotoxic investigations, whereas they have a significant meaning for medicine, ecology and national economy $[1,8,19,20]$.

For ecotoxic assessment of the state of technologically contaminated soils different methods are used $[3,17,18]$. They include chemical-analytical, bio-indicative and bio-testing methods. Each of them has its advantages and disadvantages, and only their co-application are the most objective assessment of the soils conditions, their suitability for the using for various purposes of national economy. So the spectrum of soil pollutants detected by chemical-analytical methods doesn't always make it possible to estimate their toxicity for plants, animals and humans [8]. In contrast to chemical analysis, biodiagnosis methods make it possible to estimate the presence of most soil pollutants using the test organisms in experimental or natural conditions [20]. Biodiagnosis based on the application of bioindication and bioassay methods allows detecting the presence of contaminants in the soil by changing the status of its phytobiota [16].

Bioassay methods are used to evaluate the quality of environmental objects (mainly in the laboratory) using living organisms. Using specially selected, highly sensitive to contamination the test organisms (biotesters) it's possibly to determine the integral toxicity of samples from the investigated territories, evaluate their ecological and toxicological state and possible consequences $[1,10]$.

According to the recommendations of the Special Committee on Ecological Toxicology of the International Scientific Committee on Environmental Issues, at least two biotest systems should be used to accurately assess the ecological state of an environmental object. Especial attention is paid to plant biotest systems due to their availability, simplicity and cost-effectiveness of the studies carried out on them, the reliability and consistency of the obtained results, and, importantly, they are widely used to assess soil contamination and their environmental state [5, $7,12,18]$. Another biotest-object may be animal organisms, such as Danio rerio fish, branched Cladocera crustaceans (Daphnia magna and ceriodaphnia Cladocera crustaceae) [13] and gillshape legged crustaceans, flies Drosophila melanogaster [2].

The aim of the work was the assessment of genotoxicity of edaphotopes adjacent to the surface storages of the oil processing waste of the OR with Allium-test bioassay.

\section{Materials and Methods}

The material used for the investigation was the edaphotopes adjacent to the surface storages of oil processing waste contained in the Drohobych district. The edaphotopes were selected in 2019 from the test sites (EEA), located at different distances relative to storages. EEA1 located at the distance of $10 \mathrm{~m}, \mathrm{EEA} 2$ - at the distance of $20 \mathrm{~m}, \mathrm{EEA} 3$ - $30 \mathrm{~m}$, EEA4 - $40 \mathrm{~m}$, EEA5 $50 \mathrm{~m}$, EEA6 - $100 \mathrm{~m}$, EEA7 - $200 \mathrm{~m}$. Edaphotope samples (each of $1 \mathrm{~kg}$ ) were taken at a depth of $15-20 \mathrm{~cm}$ according to the recommended methods [4]. Each mixed sample was prepared from 5 samples, mixed with each other, and immediately transported to the laboratory for further researches. Edaphotope samples were being dried in semi-sterile conditions on glass plates at room temperature $\left(20 \pm 2{ }^{\circ} \mathrm{C}\right)$ within $15-20$ days.

Preparation of aqueous extracts: pieces of edophotopes weighing $20 \mathrm{~g}$ were ground in a mortar, sieved through an aluminum perforated sieve ( $3 \mathrm{~mm}$ in diameter), $100 \mathrm{ml}$ of water were added, shaken for 10-15 min and stood for $15 \mathrm{~h}$. The resulting extracts were filtered, sterilized by holding $(15 \mathrm{~min})$ in a water bath at $100{ }^{\circ} \mathrm{C}$. The filtrates were cooled and used for further studies.

The assessment of phyto-, cyto- and genotoxicity of the investigated edaphotopes was taken by a modified variant of Allium-test in which test-object (Allium cepa bulbs of the Stuttgarter 
Riesen) was placed in aqueous extracts of edaphotopes without first germinating roots [6]. For each testing edaphotope the three independent same experiments in five times were performed. Artesian water of low mineralization was as control.

The overall toxicity of edaphotopes was assessed in a screening test using a standard plant test system of $A$. серa. The parameters of the test reaction were turgescence, discoloration, and shape of $A$. cepa bulbs grown during five days on experimental and control samples.

The phytotoxicity of edaphotopes in the Allium-test was evaluated by the phytotoxicity index of the sample $\left(\mathrm{PI}_{\%}\right)$ determined by the formula: $\mathrm{PI}_{\%}=\left(\mathrm{M}_{\mathrm{C}}-\mathrm{M}_{\mathrm{E}}\right) \times 100 \% / \mathrm{M}_{\mathrm{C}}$, where $\mathrm{M}_{\mathrm{C}}$ - the magnitude of the test reaction in control; $\mathrm{M}_{\mathrm{E}}$ - the magnitude of the test reaction in the experimental sample. The level of phytotoxicity of edaphotopes was assessed on a five-point scale [11]: 0-20\% - absent or weak level; 20.1-40\% - medial level, 40.1-60\% - above average level; $60.1-80 \%$ - high level; $80.1-100 \%$ - maximal level. The magnitude of the test reaction was the length of the roots of $A$. cepa bulbs which were grown on experimental and control aqueous extracts. The root length (in $\mathrm{mm}$ ) of bulbs was measured on the fifth day of growth (exposure time), and the mean value (M) and its error (m) were calculated.

Tolerance of $A$. cepa roots to aqueous extracts of edaphotopes in the Allium-test was evaluated by the tolerance index $\left(\mathrm{TI}_{\%}\right)$. $\mathrm{TI}_{\%}$ was determined by the root length of bulbs, and was calculated by the formula: $\mathrm{TI}_{\%}=\left(\mathrm{M}_{\mathrm{E}} / \mathrm{Mc}\right) \times 100 \%$, where $\mathrm{M}_{\mathrm{E}}$ is the average root length of A. cepa bulbs of the experimental variant; $\mathrm{Mc}$ is the average root length of the bulbs in control [9].

The cytotoxicity of edaphotopes in the Allium-test was evaluated by mitotic $\left(\mathrm{MI}_{\%}\right)$ and cytotoxic $\left(\mathrm{CI}_{\%}\right)$ indexes [15]. $\mathrm{MI}_{\%}$ is an indicator of the proliferative activity of meristem cells of roots of $A$. cepa bulbls, which was calculated by the formula: $\mathrm{MI}_{\%}=\Sigma(\mathrm{P}+\mathrm{M}+\mathrm{A}+\mathrm{T}) \times 100 \% /$ $\mathrm{N}$, where $\Sigma(\mathrm{P}+\mathrm{M}+\mathrm{A}+\mathrm{T})$ - the sum of cells undergoing pro-, meta-, ana- and telophase, and $\mathrm{N}$ is the total number of counted cells. For this purpose cytopreparations of meristem roots of $A$. сеpa bulbs grown on the test extracts and artesian water were prepared. Cytopreparations were prepared according to the method [14] which included the selection of root meristems, their fixation with Clark's solution, washing with $70 \%$ ethanol and staining with $2 \%$ acetoorsein. Microscopy of the preparations was carried out at magnification $40 \times 15$ and $90 \times 15$. The cytotoxicity index $\left(\mathrm{CI}_{\%}\right)$ was determined by the formula: $\mathrm{CI}_{\%}=\left(\mathrm{MI}_{\mathrm{E}}-\mathrm{MI}_{\mathrm{C}}\right) \times\left(\mathrm{MI}_{\mathrm{C}}{ }^{-1}\right) \times 100 \%$, where $\mathrm{MI}_{\mathrm{E}}$ is the average mitotic index of the bulb roots of $A$. cepa in test samples; $\mathrm{MI}_{\mathrm{C}}$ is the average mitotic index of the roots in control. The level of cytotoxicity of edaphotopes was assessed on a five-point scale [11]: 0-20\% - absent or weak; 20.1-40\% - medial; 40.1-60\% - above average; $60.1-80 \%$ high; 80.1-100\%-maximal.

The genotoxicity of edaphotopes was assessed by the frequencies of chromosome abberations and appearance of micronuclei induced in the root apical meristem of bulbs [14]. The frequency of chromosome abberations was determined by ana-telophase method according to Prokhorova and coauthors technique. According to the technique all ana- and telophases on cytopreparations are counted and among them cells with chromosome aberrations are detected [14]. At least 500 of ana- and telophases cells were analyzed on the cytopreparations of $A$. cepa root meristems, among which cells with different types of abberations were detected. The chromosome abberations frequency $\left(\mathrm{FM}_{\%}\right)$ was calculated by the formula: $\mathrm{FM}_{\%}=\Sigma(\mathrm{MCh}) \times 100 \% /$ $\mathrm{N}(\mathrm{A}+\mathrm{T})$, where $\Sigma(\mathrm{MCh})$ - the sum of cells with chromosome aberrations (bridges, lagging chromosomes, their fragments, vagrant chromosomes and others) at the ana- and telophase stages; $\mathrm{N}(\mathrm{A}+\mathrm{T})$ - the total number of ana- and telophases analyzed on the cytopreparations.

The frequency of the micronuclei appearance was assessed by micronucleus method [11]. At least 1000 interphase cells were analyzed on the cytopreparations of $A$. cepa root meristems 
among which cells with micronuclei were detected. The mutation frequency was calculated with the formula: $\mathrm{FMn}_{\%}=\Sigma \mathrm{I}_{\mathrm{mkn}} \times 100 \% / \Sigma \mathrm{I}$, where $\Sigma \mathrm{I}_{\mathrm{mkn}}-$ the sum of cells with micronuclei; $\Sigma \mathrm{I}-$ the total number of analyzed interphases on the cytopreparations.

The level of genotoxicity of edaphotopes was assessed by the coefficient of the mutagenic effect expression (KME, k). KME indicates in how many times the frequency of chromosomal aberrations in the experiment is higher than in the control, and it's evaluated in points. $\mathrm{KME}=$ 1-2 - mutagenic effect is absent; KME $\leq 5$ - mutagenic effect is low; KME $\leq 10$ - mutagenic effect is medial; KME $\geq 10$ - mutagenic effect is strong [15].

Statistical analysis of experimental data. Experiments were carried out in 5 repetitions. Arithmetical mean $(\mathrm{M})$, standard error of mean value $(\mathrm{m})$, the Student's ratio $(\mathrm{t})$ and the reliability index $(p)$ were determined for each selection of indices. Statistical significant effects are indicated by $p \leq 0.05$.

\section{Results and Discussion}

During the processing and production of petroleum products various waste, including oil sludge, are generated. Oil sludge is a mixture of water, mechanical impurities, chloride salts with petroleum or petroleum products, which is not to be used in production, and therefore should be sent for disposal. In case of improper storage of waste of oil refining in open-type surface storage facilities which are not equipped with restrictive means, their seepage into adjacent soils and subsequent migration of soil horizons is observed. Getting into the soil, the components of the sludge cause their contamination, imbalance, death of some organisms that inhabit the surface layers of soil [3].

For the purpose of the initial assessment of the ecotoxic state of soils adjacent to the surface storages of oil processing waste of OR (Fig. 1), they were investigated for phyto-, cyto- and genotoxicity using standard Allium-test $[6,11]$. Allium-test is a widely used method of biotesting recommended by the International Commission on Mutagenic and Carcinogenic Compounds [3], which analyzes the growth and mitotic activity of $A$. cepa bulb roots [6]. It is noted that the sensitivity of $A$. cepa as a test object is similar to the sensitivity of Chinese hamster cells and human lymphocytes - test systems for the assessment of environmental factors [18].

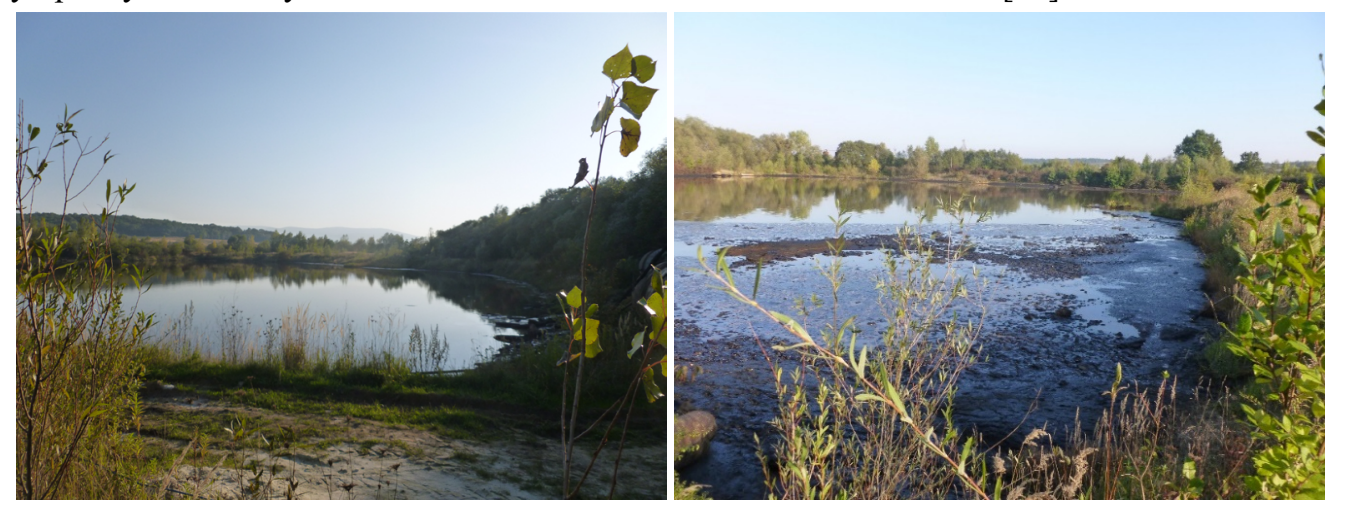

Fig. 1. Still pictures on the left and on the right - the view of sumps of the refinery

At the first stage of the Allium-test (screening test) we visually evaluated such morphological indicators as the turgescence, color, shape (swelling and bending) of the roots grown on the aqueous extracts of edaphotopes. As can be seen from Table, the turgescence of $A$. cepa bulb roots on all samples is normal, the shape is elongated and correct. But color the roots and tips of the bulb roots are different. In the sample EEA6 they are barely dark, in EEA2 - EEA5 ones - 
completely dark or black (EEA1). In control the roots and their tips were light. The change in the tested indexes of the roots indicate the presence of pollutants in the edaphotopes of the research areas located at a distance of 10-100 $\mathrm{m}$ in relation to the oil processing waste of OR.

Phytotoxicity assessment of aqueous extracts of the investigated edaphotopes in the second stage was measured by the indexes of phytotoxicity $\left(\mathrm{IP}_{\%}\right)$ and tolerance $\left(\mathrm{IT}_{\%}\right)$ [9]. According to the results (see Table) the growth activity of $A$. cepa bulb roots grown on extracts of edaphotopes, with the exception of the two studied variants (EEA6 and EEA7) is statistically lower compared to the control. The $\mathrm{IP}_{\%}$ of water extracts of EEA1 - EEA5 edaphotopes are $20.78-71.24 \%$, that indicates their average and high phytotoxic effect. The indexes of bulb roots tolerance (IT $\%)$ are determined after their length are low for EEA1 and EEA4 (Table) or medium for EEA2, EEA3, EEA5 and EEA7 samples, that confirms the negative effect of pollutants of the investigated edaphotopes on growth activity.

Morphometrical indexes of $A$. cepa bulb roots grown on aqueous extracts of edaphotopes adjacent to the surface storages of oil processing waste of OR

\begin{tabular}{|c|c|c|c|c|c|}
\hline \multirow{2}{*}{$\begin{array}{l}\text { Samples of } \\
\text { edaphotopes }\end{array}$} & \multicolumn{2}{|c|}{$\begin{array}{l}\text { Morphological indices of } \\
\text { Allium cepa roots }\end{array}$} & \multirow{2}{*}{$\begin{array}{l}\text { Roots length } \\
(\mathrm{M} \pm \mathrm{m}), \mathrm{mm} ; \\
\left(\mathrm{t}^{*} ; \leq \mathrm{p}^{* *}\right)\end{array}$} & \multicolumn{2}{|c|}{ Indexes } \\
\hline & $\begin{array}{l}\text { Turgescence \& } \\
\text { Shape }\end{array}$ & Colour & & $\begin{array}{l}\text { Phytotoxicity index } \\
\left(\mathrm{IP}_{\%}\right) ; \text { toxicity level }\end{array}$ & $\begin{array}{c}\text { Tolerance index } \\
\left(\mathrm{IT}_{\%}\right) ; \text { tolerance level }\end{array}$ \\
\hline Control & $\begin{array}{c}\text { Normal; } \\
\text { lengthened } \\
\text { regular (normal) }\end{array}$ & $\begin{array}{l}\text { Light with light } \\
\text { tips (normal) }\end{array}$ & $38.88 \pm 1.82$ & & \\
\hline EEA1 & Normal & $\begin{array}{c}\text { Black with dark } \\
\text { tips }\end{array}$ & $\begin{array}{c}12.88 \pm 1.19 \\
(11.96 ; 0.01)\end{array}$ & $\begin{array}{c}66.87 \% \\
\text { high level }\end{array}$ & $\begin{array}{c}33 \% ; \\
\text { low level }\end{array}$ \\
\hline EEA2 & Normal & $\begin{array}{c}\text { Dark with dark } \\
\text { tips }\end{array}$ & $\begin{array}{l}22.6 \\
(5.00\end{array}$ & $\begin{array}{c}41.64 \% ; \\
\text { above average level }\end{array}$ & $\begin{array}{c}58 \% \\
\text { medium level }\end{array}$ \\
\hline EEA3 & Normal & $\begin{array}{c}\text { Dark with dark } \\
\text { tips }\end{array}$ & $\begin{array}{l}20.02 \pm 1.95 \\
(7.07 ; 0.01)\end{array}$ & $\begin{array}{c}48.04 \% \\
\text { above average level }\end{array}$ & $\begin{array}{c}51 \% \\
\text { medium level }\end{array}$ \\
\hline EEA4 & Normal & $\begin{array}{c}\text { Dark with dark } \\
\text { tips }\end{array}$ & $\begin{array}{c}11.18 \pm 1.01 \\
(13.31 ; 0.01)\end{array}$ & $\begin{array}{l}71.24 \% \\
\text { high level }\end{array}$ & $\begin{array}{c}29 \% \\
\text { low level }\end{array}$ \\
\hline EEA5 & Normal & $\begin{array}{c}\text { Dark with dark } \\
\text { tips }\end{array}$ & $\begin{array}{l}20.19 \pm 1.01 \\
(8.98 ; 0.01)\end{array}$ & $\begin{array}{c}48.07 \% \\
\text { above average level }\end{array}$ & $\begin{array}{c}52 \% \\
\text { medium level }\end{array}$ \\
\hline EEA6 & Normal & $\begin{array}{l}\text { Light with dark } \\
\text { tips }\end{array}$ & $\begin{array}{l}33.14 \pm 1.73 \\
(2.29 ; 0.02)\end{array}$ & $\begin{array}{l}14.76 \% \\
\text { low level }\end{array}$ & $\begin{array}{c}85 \% \\
\text { high level }\end{array}$ \\
\hline $\begin{array}{c}\text { EEA7 } \\
\text { t - Studen }\end{array}$ & $\begin{array}{l}\text { Normal } \\
\text { ratio; **p-re }\end{array}$ & $\begin{array}{l}\text { Normal } \\
\text { ility index }\end{array}$ & $\begin{array}{l}30.80 \pm 1.47^{*} \\
(3.45 ; 0.01)\end{array}$ & $\begin{array}{c}20.78 \% ; \\
\text { medium level }\end{array}$ & $\begin{array}{c}79 \% ; \\
\text { medium level }\end{array}$ \\
\hline
\end{tabular}

The last ones were obtained with calculating cells at the different stages of mitosis. To determine the target of mitosis modifying action of the pollutants of edaphotopes, phase indexes of the root meristems were calculated. The last ones were obtained with calculating cells at the different stages of mitosis (Fig. 3). As can be seen from the Fig. 2, the mitotic indexes of the root meristem in five investigated samples EEA1 - EEA5 are significantly lower comparing to the control (multiplicity values are $0.77-0.62$ ). It should be noted that the prophase indexes of these edaphotopes samples are higher compared to the control (48.19\%) (Fig. 3). These results indicate the delay of the processes in the prophase associated with the condensation of chromosomes and their subsequent transition to the metaphase stage. Confirmation of this assumption is that the metaphase indexes of these experimental samples (EEA1 - EEA5) are lower than the control one. It can be explained by the decreased activity of the proteins responsible for the formation of the metaphase plate, for proper positioning and orientation of homologous chromosomes on it. In addition, the anaphase index of the root apical meristem in sample EEA3 is lower than the 
control one and other edaphotope samples. This might indicate the ability of the pollutants of edaphotope, which are extracted with water, at higher concentrations to interfere with the normal formation of fission spindles and chromosome segregation.

Thus, the pollutants of the test edaphotope samples EEA1 - EEA5 have a negative effect on the course of processes in mitosis, especially in prophase and anaphase, showing mitosomodifying effect.

In other experimental samples (EEA6 and EEA7) there was a slight effect of edaphotope pollutants on mitotic activity of the root - there mitotic indexes are close to control (Fig. 2). For EEA6 and EEA7 the cytotoxic effect of their extracts is absent at all: the cytotoxicity indexes are low -2.37 and 3.55, respectively (Fig. 2). The weaker mitotoxic effect of these edaphotopes can be explained by their longer distance $(100$ and $200 \mathrm{~m})$ from the oil processing waste of OR. In addition, the phase indexes of these experimental samples are close to control. This ratio of phase indexes according to the literature is typical for the mitotic activity of $A$. cepa roots [6].

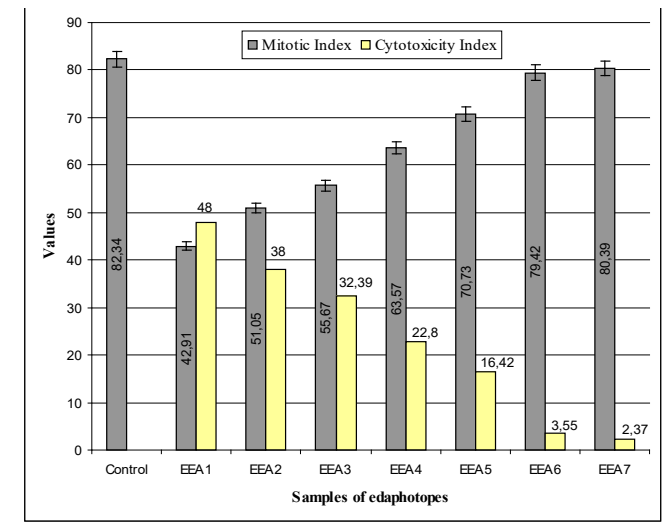

Fig. 2. Mitotic and cytotoxicity indexes of meristem cells of $A$. cepa bulb roots grown on aqueous extracts of the samples of edaphotopes

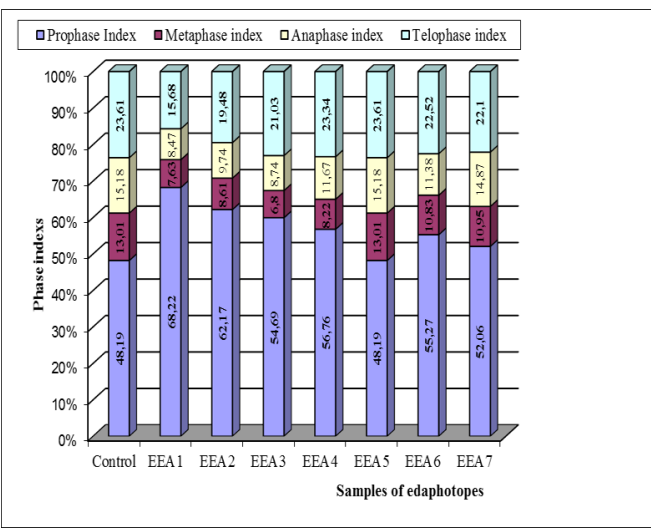

Fig. 3. Phase indexes of mitotic activity of meristem cells of $A$. cepa bulb roots grown on aqueous extracts of the samples of edaphotopes

So it was found that edaphotopes located at a distance of $10-50 \mathrm{~m}$ relative to the storages of oil processing waste of $\mathrm{OR}$ have a high and average cytotoxic effect (depending on the distance) on the proliferative activity of the test-object $A$. cepa meristem cells: their mitotic index are reduced to $51.05-63.57 \%$ (normal $-82.34 \%$ ), and cytotoxicity index increases up to $22.8-48.0 \%$.

The genotoxicity assessment of technologically modified edaphotopes by the activity of the OR was carried out by ana-telophase method [14]. Ana-telophase method was combined with a micronucleus test [15]. The results of the studies are shown on Fig. 4 and Fig. 5. As we can see (Fig. 4), the frequency of chromosome aberrations in the meristem cells of $A$. cepa bulb roots induced by aqueous extracts of EEA1 - EEA5 sample edaphotopes was increased up to $2.32-4.12 \%$ comparing to the control. Coefficient of the mutagenic effect expression (KME) was 2.73-4.85, indicating the low level of genotoxicity. For EEA6 - EEA7 samples the frequency of chromosome aberrations is close to the control. KME is not higher than 2. It indicates the absence of pronounced genotoxicity of edaphotopes located at the distance $100 \mathrm{~m}$ and $200 \mathrm{~m}$ in relation to the storages of oil processing waste. It should be noted that among the interphase cells of the meristem grown on the aqueous extracts of EDD1 - EDD5 sample edaphotopes, a significant proportion were cells with micronuclei (Fig. 6, B). In particular, the frequency of interphase cells with micronuclei is $1.97-3.60 \%$ (0.30\% in control), and KME is 6.57-12.00 (Fig. 5). It 
indicates on the medial and high level of genotoxicity of aqueous extracts of EDD1 - EDD5 edaphotopes (see Fig. 6, B). These indexes are especially high ( $\mathrm{k}>10)$ for EDD1, EDD2 and EDD4 sample edaphotopes which are located at a distance of $10-40 \mathrm{~m}$ in relation to the storages of oil processing waste of the OR.

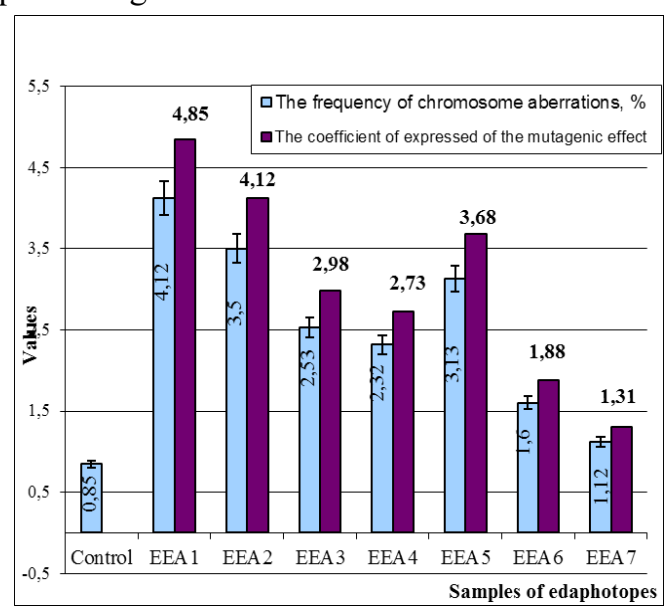

Fig. 4. Frequency of chromosome aberrations in mitotic phases of $A$. cepa root tip cells grown on aqueous extracts of the samples of edaphotopes

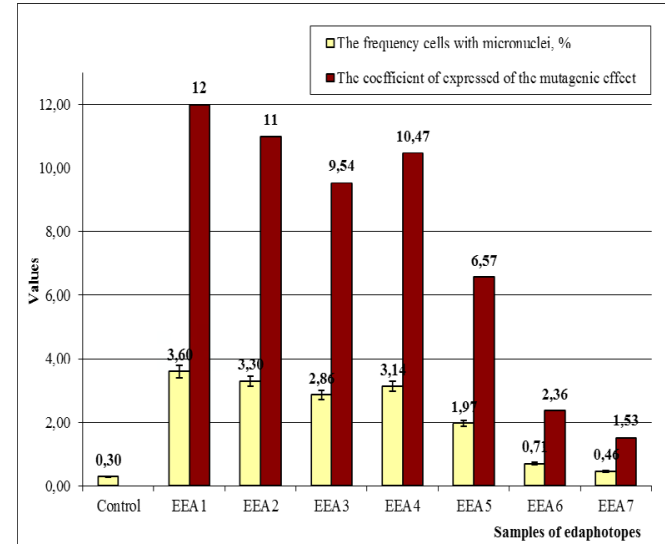

Fig. 5. Frequency of cells with micronuclei in meristem of $A$. cepa root tip cells grown on aqueous extracts of the samples of edaphotopes

In the ana-telophase test on cytopreparations of apical meristem cells of $A$. cepa bulb roots grown on aqueous extracts of EDD1 - EDD5 edaphotopes different types of disorders during the chromosomes divergence to the poles of spindle were revealed. Among them - chromosome lagging, formation of single and paired fragments and bridges which may be the result of deletions and translocations of chromosomes (Fig. 6, A). The high frequency of chromosome aberrations can be explained by the fact that the oil processing waste seeps into the adjacent soils from their storages. Since they are present in the studied edaphotopes in sufficiently high quantities they are highly likely to induce various types of chromosome aberrations - most often micronuclei in the meristem cells of test object $A$. cepa.
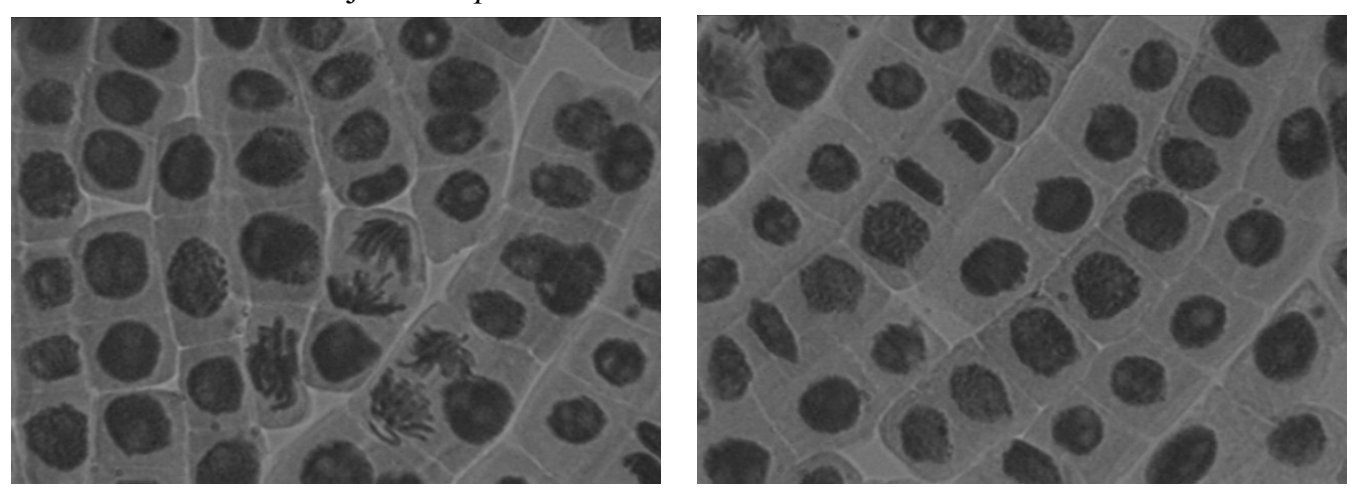

Fig. 6. Meristematic cells of root tips of A. cepa with chromosome aberrations (A) and micronuclei (B)

So it was shown that edaphotopes located at a distance of 10-50 m relative to the storages of oil processing waste of the OR are impregnated with the same waste and are toxic. Their 
aqueous extracts cause a medium and high level of phyto-, cyto- and genotoxic effects on the morphogenesis of the plant test object $A$. cepa depending on their location. Remote edaphotopes (up to 100-200 m) have lower phyto-, cyto- and genotoxic effects which are close to the levels of the spontaneous one.

\section{REFERENCES}

1. Ball N., Madden J., Paini A. et al. Key read across framework components and biology based improvements // Mutat. Res. Genet. Toxicol. Environ. Mutagen. 2020. Vol. 853. https://doi. org/10.1016/j.mrgentox.2020.503172.

2. Bodnar I., Gorbulinska S., Bodnar L. Expediency of use vitamin chemioprotectors for correction of chromosome aberration induced by food synthetic flavors "Caramel" // Visnyk of the Lviv University. Series Biology. 2017. Iss. 76. P. 54-60 [in Ukrainian].

3. Citterio S., Aina R., Labra M. Soil Genotoxicity Assessment: A New Strategy based on Biomolecular Tools and Plant Bioindicators // Environ. Sci. Technol. 2002. Vol. 36. Iss. 12. P. 2748-2753. https://doi.org/10.1021/es0157550.

4. Datta S., Singh J., Singh J. Assessment of genotoxic effects of pesticide and vermicompost treated soil with Allium cepa test // Sustain. Environ. Res. 2018. Vol. 28. Iss. 4. P. 171-178. https://doi.org/10.1016/j.serj.2018.01.005.

5. Farizan A., Norfatimah M. Y., Aili Z. N. et al. Use of cytological and molecular biological method for water pollution monitoring // IOP Conf. Series: Earth and Environmental Science. 2021. doi:10.1088/1755-1315/674/1/012108.

6. Fiskesjo G. The Allium test as a standard in environmental monitoring // Hereditas. 1985. Vol. 102. P. 99-112.

7. Haq I., Kalamdhad S. Phytotoxicity and cyto-genotoxicity evaluation of organic and inorganic pollutants containing petroleum refinery wastewater using plant bioassay // Environ. Technol. Inno. 2021. Vol. 23. https://doi.org/10.1016/j.eti.2021.101651.

8. Herrero O., Pérez J. M., Fernández M. P. et al. Toxicological evaluation of three contaminants of emerging concern by use of the Allium cepa test // Mutat. Res. Genet. Toxicol. Environ. Mutagen. 2012. Vol. 743. Iss. 1-2. P. 20-24. https://doi.org/10.1016/j.mrgentox.2011.12.028.

9. Konotop Ye. O., Kovalenko M. S., Ulynets V. Z. et al. Phytotoxicity of colloidal solutions of metal-containing nanoparticles // Cytol. Genet. 2014. Vol. 48. P. 98-102. https://doi. org/10.3103/S0095452714020054.

10. Kwasniewska J., Nałęcz-Jawecki G., Skrzypczak A. et al. An assessment of the genotoxic effects of landfill leachates using bacterial and plant tests // Ecotoxicol. Environ. Safe. 2012. Vol. 75. P. 55-62. https://doi.org/10.1016/j.ecoenv.2011.08.020.

11. Leme D. N., Marin-Morales M. A. Allium cepa test in environmental monitoring: A review on its application // Mutation Research. 2009. Vol. 682. Iss. 1. P. 71-81.

12. Martins M., Ventura de Souza V., Souza T. Cytotoxic, genotoxic and mutagenic effects of sewage sludge on Allium cepa // Chemosphere. 2016. Vol. 148. P. 481-486. https://doi. org/10.1016/j.chemosphere.2016.01.071.

13. Pellegri V., Gorbi G., Buschini A. Comet Assay on Daphnia magna in eco-genotoxicity testing // Aquat. Toxicol. 2014. Vol. 155. P. 261-268. doi: 10.1016/j.aquatox.2014.07.002.

14. Prokhorova I. M., Kovaleva M. I., Fomicheva A. N. Assessment of cytotoxic and mutagenic effects of environmental factors: guidelines. Yaroslavl: Yaroslavl State University, 2003. 32 p. [in Russian].

15. Prokhorova I. M., Kovaleva M. I. A system of tests for assessing the genotoxic activity of 
environmental factors. Yaroslavl: Yaroslavl State University, 2001. 23 p. [in Russian].

16. Radic S., Stipaničev D., Vujčić $V$. et al. The evaluation of surface and wastewater genotoxicity using the Allium cepa test // Sci. Total Environ. 2010. Vol. 408. Iss. 5. P. 1228-1233. https:// doi.org/10.1016/j.scitotenv. 2009.11.055.

17. Rank $J$. The method of Allium anaphase telophase chromosome aberration assay // Ecologia (Vilnius). 2003. № 1. P. 38-42.

18. Stapulionyte A., Kleizaite V., Šiukšta R. et al. Cyto/genotoxicological evaluation of hot spots of soil pollution using Allium bioassays in relation to geochemistry // Mutat. Res. Genet. Toxicol. Environ. Mutagen. 2019. Vol. 842. P. 102-110. https://doi.org/10.1016/j.mrgentox.2019.01.001.

19. Steiblen G., van Benthem J., Johnson G. Strategies in genotoxicology: Acceptance of innovative scientific methods in a regulatory context and from an industrial perspective // Mutat. Res. Genet. Toxicol. Environ. Mutagen. 2020. Vol. 853. https://doi.org/10.1016/j.mrgentox.2020.503171.

20. Yadav A., Raj A., Purchase D. et al. Phytotoxicity, cytotoxicity and genotoxicity evaluation of organic and inorganic pollutants rich tannery wastewater from a Common Effluent Treatment Plant (CETP) in Unnao district, India using Vigna radiata and Allium cepa // Chemosphere. 2010. Vol. 224. P. 324-332. https://doi.org/10.1016/j.chemosphere.2019.02.124.

Стаття надійшла до редакиії 22.04.21

доопрацьована 08.06.21

прийнята до друку 09.06.21

\title{
ОЦІНКА ЕКОТОКСИЧНОГО СТАНУ ТЕХНОГЕННО-ЗМІНЕНИХ ЕДАФОТОПІВ ВІДХОДАМИ НАФТОПЕРЕРОБНОГО ЗАВОДУ

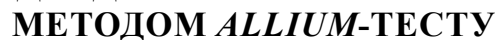

\author{
Г. Клепач ${ }^{1 *}$, Н. Голуб ${ }^{2}$, О. Лупак ${ }^{1}$ \\ ${ }^{1}$ Дрогобицький державний педагогічний університет імені Івана Франка \\ вул. I. Франка, 24, Дрогобич 82100, Украӥна \\ e-mail:pavlishko@yahoo.com \\ ${ }^{2}$ Львівський національний університет імені Івана Франка \\ вул. Грушевського, 4, Львів 79005, Украӥна \\ e-mail:nataliia.holub@lnu.edu.ua
}

\begin{abstract}
Досліджено екотоксичний стан техногенно-змінених едафотопів відходами нафтопереробного заводу методом Allium-тесту. Матеріалом для досліджень слугували зразки едафотопів, відібрані на глибині 15-20 см зі семи дослідних ділянок, розміщених на відстані 10-200 м від поверхневих сховищ відходів нафтопереробного заводу. У Allium-тесті виявлено, що зразки едафотопів ділянок, локалізованих на відстанях 10-50 м від сховищ відходів нафтопереробного заводу, є токсичними. Зокрема, їхні водні витяжки спричиняли фіто-, цито- і генотоксичну дії середнього й високого рівнів стосовно ростової та проліферативної активності корінців цибулин Allium сера сорту Stuttgarter Riesen. У ростовому Allium-тесті зазначені витяжки едафотопів спричиняли потемніння корінців і почорніння їхніх кінчиків (на противагу світлим корінцям зі світлими кінчиками у контролі). До того ж їхня ростова активність на водних витяжках едафотопів була знижена в 1,71-3,5 разу залежно від їхньої локації та віддаленості від поверхневого сховища відходів нафтопереробного заводу. Фітотоксичність водних витяжок досліджених едафотопів стосовно $A$. сера є вище
\end{abstract}


середнього і високого рівнів, а толерантність корінців тест-об'єкта до них знижується до 29-52 \% порівняно з контролем. Мітотична активність апікальної меристеми корінців цибулин $A$. сера також знижується. Зокрема, їхні мітотичні індекси спадають до 51,05-63,57 \% (за норми 82,34 \%), а індекси цитотоксичності зростають до 22,848,0 \%, що свідчить про середній рівень цитотоксичності досліджених едафотопів на проліферативну активність тест-об'єкта. За допомогою анателофазного методу і мікроядерного тесту показано, що частота хромосомних аберацій і поява мікроядер у клітинах апікальної меристеми корінців $A$. сера $є$ вищою у $3,34-5,20$ разу порівняно 3 контролем, а це вказує на середній і високий рівні генотоксичності досліджених едафотопів. Едафотопи, розташовані на відстані 100-200 м від поверхневих сховищ відходів нафтопереробного заводу, мають слабку фіто- , цито- і генотоксичну дію, яка $€$ близькою до фонового рівня.

Ключові слова: відходи нафтопереробного заводу, едафотопи, Allium-тест, екотоксичність 